\title{
СТАН ДОБОВОГО ДІУРЕЗУ НИРОК В УМОВАХ ІШЕМІЧНО-РЕПЕРФУЗІЙНОГО СИНДРОМУ КІНЦІВОК, ТРАВМИ ОРГАНІВ ЧЕРЕВНОЇ ПОРОЖНИНИ, УСКЛАДНЕНОї ГІПОВОЛЕМІЧНИМ ШОКОМ, ТА ЇХ ПОЄДНАННЯ У РАННЬОМУ ПЕРІОДІ ТРАВМАТИЧНОЇ ХВОРОБИ
}

\section{ДВНЗ «Тернопільський державний медичний університет імені І. Я. Горбачевського МОЗ України»}

РЕЗЮМЕ. Мета роботи - вивчити вплив ішемічно-реперфузійного синдрому на функціональний стан нирок у ранньому післятравматичному періоді.

Матеріал і методи. В експерименті використали 80 статевозрілих білих щурів-самців лінії Wistar мacoю 190220 г, які перебували на стандартному раціоні віварію.

Усіх тварин поділили на групи: контрольну і 3 дослідних (по 8 тварин у кожній групі). У тварин першої дослідної групи під тіопенталонатрієвим знеболенням (40 мг·Кг ${ }^{-1}$ проксимально на задні лапки накладали кровоспинний джгут терміном на 120 хв. У другій дослідній групі було змодельовано поєднану травму органів черевної порожнини шляхом нанесення двох дозованих ударів у ділянку черевної порожнини; гіповолемічний шок моделювали шляхом кровопускання від 20 до 22 \% об'єму циркулюючої крові з стегнових судин. У третій дослідній групі моделювали поєднану травму органів черевної порожнини та реперфузію кінцівок. Тварин контрольної групи вводили тільки в наркоз.

Через 1, 3 і 7 діб у піддослідних тварин визначали функціональний стан нирок методом водного навантаження. Оцінювали величину діурезу та швидкість клубочкової фільтрації.

Тварин дослідних груп виводили з експерименту в умовах тіопенталонатрієвого наркозу методом тотального кровопускання з серця.

Результати. В групі тварин після накладання джгутів на задні кінцівки після першої доби істотно знижувався та мав мінімальні значення діурез, згодом показник збільшувався, однак не досягав рівня контрольної групи навіть через 7 діб (менше на 33,6 \%, (р<0,05) порівняно з контролем). У групі тварин з травмою органів черевної порожнини та гіповолемічним шоком показник досягав мінімального рівня через 3 доби та фактично залишався на тому ж рівні до сьомої доби. У групі тварин, яким поєднували травму органів черевної порожнини, кровотечу та накладання джгутів на задні кінцівки, спостерігали тенденцію до постійного зниження показника протягом усього часу спостереження. Його мінімальні значення зафіксували через 7 діб (на 33,6 \% (р<0,05) менше, порівняно 3 контролем). Швидкість клубочкової фільтрації знижувалась у всіх групах піддослідних тварин. Наростання показника протягом часу спостереження визначено в групі тварин, яким накладали джгути, хоча навіть після 7 доби він залишався удвічі меншим за контрольні показники. В групі тварин з травмою органів черевної порожнини та гіповолемічним шоком показник досягав мінімальних значень через 3 доби та залишався на цьому рівні до кінця спостереження, що відповідає класичній картині патофізіологічних змін в моделі поєднаної травми. Найвираженішими зміни були у тварин з поєднанням травми та ішемічно-реперфузійного синдрому. Значне зниження показника фіксували усіх контрольних точках спостереження.

КлючОВІ словА: діурез; нирки; травма; реперфузійний синдром; експеримент.

Вступ. На сьогодні травма залишається актуальною медичною та соціальною проблемою. За даними ВООЗ, у структурі причин смертності травми займають третє, а серед населення до 40 років - перше місце [1]. Загальною тенденцією останніх років $\epsilon$ збільшення кількості випадків поєднаної травми, ускладненої масивною кровотечею, зокрема внаслідок збільшення кількості дорожньо-транспортних пригод та внаслідок застосування вибухових речовин, тобто висококінетичних травм [2].

Як зазначають дослідники, у патогенезі травматичних розладів важливу роль відіграє розвиток ниркової недостатності, особливо у постраждалих з гіповолемічним шоком [3-5]. Відомі роботи, у яких показано, що в ранньому періоді поєднаної травми в експерименті виникає олігурія внаслідок зниження швидкості клубочкової фільтрації $[9,10]$.
Однак роботи, пов'язані з дослідженням впливу ішемічно-реперфузійного синдрому при поєднаній травмі, в період ранніх проявів травматичної хвороби (до 7 доби), на функціональний стан нирок фактично відсутні. Період ранніх проявів травматичної хвороби має важливе значення в патогенезі травматичної хвороби, адже саме в цей час виникають основні патофізіологічні зміни, які згодом визначають перебіг післятравматичного періоду та віддалені наслідки $[6,7]$.

Мета роботи - вивчити вплив ішемічно-реперфузійного синдрому на функціональний стан нирок у ранньому післятравматичному періоді.

Матеріал і методи дослідження. Робочою гіпотезою експериментального дослідження $\epsilon$ припущення, що використання кровоспинного джгута та наступна реперфузія ішемізованих тканин чинить системний вплив на організм з пору- 
Огляди літератури, оригінальні дослідження, погляд на проблему, ювілеї

шенням життєдіяльності внутрішніх органів при поєднаній травмі органів черевної порожнини на фоні гіповолемічного шоку, та може стати причиною розвитку поліорганної недостатності.

3 метою реалізації поставленої мети було виконано експериментальне дослідження на 80 нелінійних щурах-самцях масою 190-220 г. Усіх тварин поділили на групи: контрольну і 3 дослідних (по 8 тварин у кожній групі).

Тваринам першої дослідної групи (ГД-1) під тіопенталонатрієвим знеболюванням (40 мг·кг $\left.{ }^{-1}\right)$ проксимально на задні лапки накладали кровоспинний джгут терміном на 120 хв. Як джгут застосовували еластичну смужку джгута «SWAT-T» (США) завширшки 10 мм, що відповідає ширині джгута при накладанні на стегно дорослій людині. Джгут затягували відповідно до нанесеного на ньому індикатора ефективного тиску. Накладання кровоспинного джгута терміном на дві години виконували з метою моделювання ішемічно-реперфузійного синдрому.

Тваринам другої дослідної групи (ГД - 2) моделювали поєднану травму органів черевної порожнини: після проведення наркозу тіопенталом натрію (40 мг·кг') тварині наносили два дозованих удари у ділянку черевної порожнини за допомогою спеціального пристрою - силу нанесення удару розраховували таким чином, щоб не виникала внутрішня кровотеча; крововтрату моделювали шляхом виконання операційного доступу і пересікання стегнових судин в об'ємі від 20 до $22 \%$ об'єму циркулюючої крові тварини протягом однієї хвилини (гостра крововтрата), після чого кровотечу зупиняли шляхом перев'язування судин.

У третій дослідній групі (ГД - 3) моделювали поєднану травму органів черевної порожнини та ішемічно-реперфузійний синдром відповідно до методик, описаних вище.

Тварин дослідних груп виводили з експерименту в умовах тіопенталонатрієвого наркозу (60 мг·кг ${ }^{-1}$ ) методом тотального кровопускання 3 серця через 1, 3 та 7 діб після реперфузії. Для дослідження забирали нирки тварин. Тварин контрольної групи (КГ) тільки вводили в наркоз, застосовуючи еквівалентну дозу тіопенталу натрію, і в подальшому виводили з експерименту через 2 год. Отримані дані порівнювалися з КГ.

Через 1, 3 і 7 діб визначали функціональний стан нирок піддослідних тварин методом водного навантаження [8]. Метод використовували за 2 години до евтаназії шляхом виконання наступних дій: у шлунок вводили підігріту до $30^{\circ} \mathrm{C}$ водогінну воду в об'ємі 5 \% від маси тіла піддослідної тварини. Далі протягом 2 годин у піддослідних тварин збирали сечу. Після забору сечі під тіопенталонатрієвим знеболюванням, відповідно до положень Європейської конвенції щодо захисту хребетних тварин, яких використовують для експериментальних та інших наукових цілей (Страсбург, 1985), проводили евтаназію методом тотального кровопускання із серця. Оцінювали величину діурезу та швидкість клубочкової фільтрації.

Дослідження зазначених показників визначали в Центральній науковій лабораторії Тернопільського державного медичного університету імені І. Я. Горбачевського.

Вірогідність відмінностей між контрольною і дослідними групами оцінювали з використанням непараметричного критерію Манна-Уітні. Відмінності вважали істинними при вірогідності нульової гіпотези менше $5 \%(p<0,05)$.

Результати й обговорення. Аналіз динаміки діурезу (табл. 1) показав, що у ГД-1 через 1 добу він ставав меншим від рівня контролю на 46,6 \% ( $p<0,001)$, через 3 доби - на 44,3\%, ( $p<0,001)$ через 7 діб - на 33,6 \% (p<0,001). В ГД-2 через 1 добу діурез зменшився на 36,1 \% ( $<<0,001)$, через 3 доби - на 44,6 \% ( $<<0,001)$, через 7 діб - на 44,1 \% ( $p<0,001)$. В ГД-3 через 1 добу діурез знизився на 49,9\%, через 3 доби - на 58,9\%, через 7 діб - на $70,5 \%$ порівняно з контролем ( $p<0,001)$.

Таблиця 1. Діурез (мкл·хв-1) з розрахунку на 100 г маси тварини в динаміці у групах дослідження, Me (LQ;UQ) - медіана (нижній і верхній квартилі)

\begin{tabular}{|c|c|c|c|c|}
\hline \multirow{2}{*}{ Групи дослідження } & \multirow{2}{*}{ Контроль } & \multicolumn{3}{|c|}{ Термін дослідження } \\
\hline & & 1 доба & 3 доба & 7 доба \\
\hline ГД-1 & \multirow{3}{*}{$\begin{array}{c}38,77 \\
(37,90 ; 40,57) \\
(n=8)\end{array}$} & $\begin{array}{c}20,69^{* * *} \\
(19,72 ; 21,41)(n=8)\end{array}$ & $\begin{array}{c}22,38^{* * *} \\
(21,68 ; 23,81)(n=8)\end{array}$ & $\begin{array}{c}25,74^{* * *} \\
(24,64 ; 28,98)(n=8)\end{array}$ \\
\hline гД-2 & & $\begin{array}{c}24,76^{* *} \\
(24,36 ; 26,85)(n=8)\end{array}$ & $\begin{array}{c}21,46^{* * *} \\
(19,55 ; 22,38)(n=8)\end{array}$ & $\begin{array}{c}21,68^{* * *} \\
(20,28 ; 23,44)(n=8)\end{array}$ \\
\hline ГД- 3 & & $\begin{array}{c}19,44^{* * *} \\
(18,99 ; 19,72)(n=8)\end{array}$ & $\begin{array}{c}15,95^{* * *} \\
(14,52 ; 16,42)(n=8)\end{array}$ & $\begin{array}{c}11,43^{* * *} \\
(10,49 ; 12,78)(n=8)\end{array}$ \\
\hline$P_{1-2}$ & & $<0,01$ & $>0,05$ & $<0,05$ \\
\hline$P_{1-3}$ & & $>0,05$ & $<0,001$ & $<0,001$ \\
\hline $\mathrm{P}_{2-3}$ & & $<0,001$ & $<0,001$ & $<0,001$ \\
\hline
\end{tabular}

Примітки: тут і в інших таблицях: $1 .{ }^{*}$ достовірність відмінностей стосовно контрольної групи $\left({ }^{*}-p<0,05 ;{ }^{* *}-p<0,01 ;{ }^{* * *}-p<0,01\right)$.

2. $\mathrm{p}_{1-2}$ - достовірність відмінностей показника між групами тварин ГД-1 та ГД-2; $\mathrm{p}_{1-3}-$ між ГД- 1 та ГД-3; $\mathrm{p}_{2-3}-$ між ГД-2 та ГД-3. 
Огляди літератури, оригінальні дослідження, погляд на проблему, ювілеї

Порівнюючи величину діурезу в дослідних групах за термінами спостереження ми виявили, що в ГД-3 через 1 добу цей показник був меншим, ніж у ГД-1 і ГД-2 (відповідно на 6,4 і 27,4%, $\left.\mathrm{p}_{1-3}>0,05, \mathrm{P}_{2-3}<0,001\right)$. Через 3 доби діурез у ГД - 3 залишався істотно нижчим, порівняно з ГД - 1, та ГД - 2 (відповідно на 40,3 і 34,5\%, р $_{1-3}<0,001$, $\left.\mathrm{p}_{2-3}<0,001\right)$. Достовірної різниці між показниками в ГД-1 та ГД-2 через три доби не спостерігалось. Через 7 діб в ГД-3 величина діурезу була суттєво меншою, ніж в ГД-1 та ГД-2 (відповідно на $125,2 \%, \mathrm{p}_{1-3}<0,001$ і на $\left.89,7 \%, \mathrm{p}_{2-3}<0,001\right)$. Також в ГД-1 показник був на 18,7 \% більше ніж у ГД-2 $\left(p_{1-2}<0,05\right)$.

Аналізуючи динаміку діурезу у дослідних групах ми встановили (рис. 1), що у ГД-1 показник через 3 доби ставав істотно більшим, ніж на 1 добу (на 8,2\%, р<0,01), а через 7 діб статистично достовірно більшим, ніж 3 добу (на 14,3 \%, р<0,001), однак не досягав рівня контрольної групи.

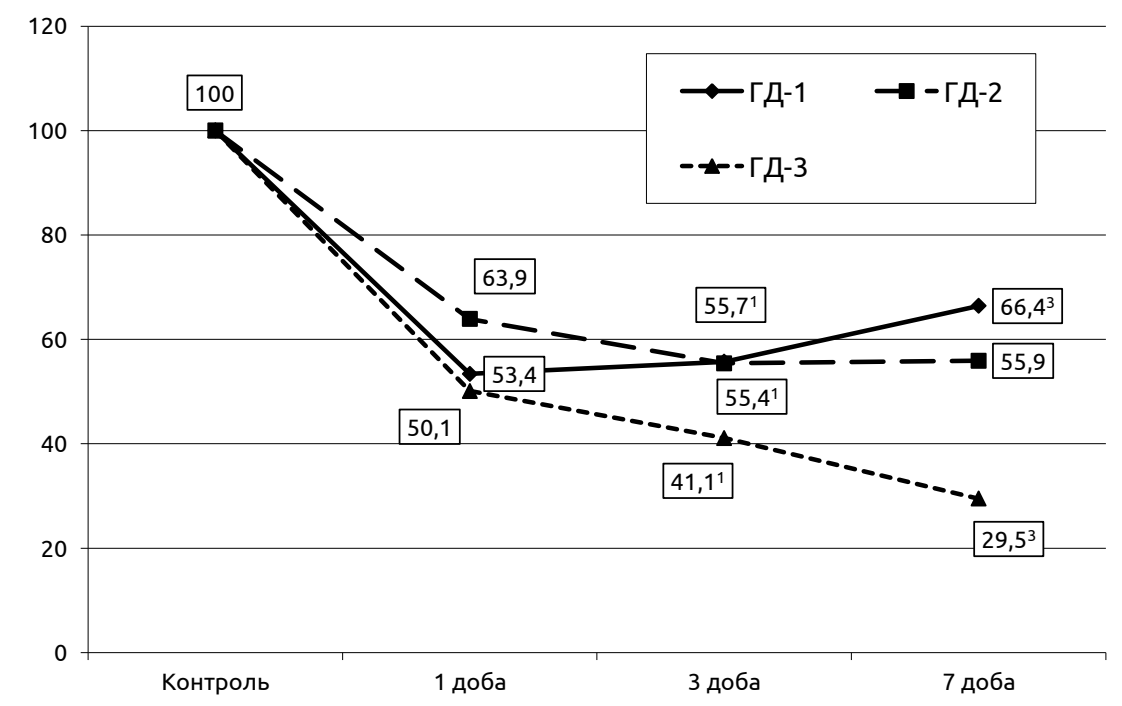

Рис. 1. Динаміка діурезу (у відсотках стосовно контрольної групи) в групах дослідження.

(Примітка. Тут і на інших рисунках: 1,3 - відмінності стосовно 1 і 3 діб спостереження статистично достовірні, p<0,05).

В ГД-2 діурез через 3 доби знижувався і виявився істотно меншим, ніж на 1 добу (на 13,3 \%, p<0,01). Через 7 діб він фактично не змінювався та залишався на рівні 3 доби ( $>>0,05)$. В ГД-3 спостерігалась тенденція до поступового зниження показника з 1 до 7 діб: через 3 доби він ставав меншим за попередній термін спостереження на $18,1 \%(p<0,01)$, а через 7 діб - на 24,4 \%, порівняно із результатом 3 доби ( $p<0,01)$.

У групі тварин після накладання джгутів на нижні кінцівки після першої доби істотно знижувався діурез та мав мінімальні значення протягом всього часу спостереження, в подальшому показники збільшувалися, однак не досягали рівня в контрольній групі навіть через 7 діб. В ГД-2 показник досягав мінімального рівня через 3 доби та фактично залишався на тому ж рівні через сім діб. У групі тварин, у яких поєднували травму органів черевної порожнини, кровотечу та накладання джгутів на нижні кінцівки, спостерігали тенденцію до постійного зниження показника протягом усього часу спостереження. Його мінімальні значення зафіксували через 7 діб. Також слід зазначити, що він був значно меншим, порівняно з показниками в ГД-1 та ГД-2. На нашу думку, важли- вим також є той факт, що в ГД-1 та ГД-2 показники хоч і відрізнялись, однак незначно.

у свою чергу, швидкість клубочкової фільтрації (табл. 2) у всіх групах дослідження істотно зменшувалася з першої до 7 доби посттравматичного періоду, порівняно з контрольною групою. В ГД-1 через 1 добу цей показник знижувався на 63,8 \%, через 3 доби дещо зростав, однак залишався меншим за контрольні значення на 47,4 \%, через 7 діб на 45,4\% ( $<<0,001)$. В ГД-2 через 1 добу він ставав меншим на 59,6 \%, через 3 доби - на 66,9 \%, через 7 діб - на 66,2 \% (р<0,001). В ГД-3 зниження клубочкової фільтрації у посттравматичному періоді становило відповідно 71,3, 74,8 і 81,7 \% ( $><0,001)$.

Порівнюючи величину клубочкової фільтрації в дослідних групах за термінами спостереження ми виявили, що через 1 добу в ГД-3 цей показник виявився статистично достовірно меншим, ніж у ГД-1 і ГД-2 (відповідно на 26,2%, р $_{1-3}<0,01$ і 41,1 \%, $\left.\mathrm{p}_{2-3}<0,05\right)$. У ГД-2 показник був на 11,8 \% більшим, однак статистично різниця не була достовірною $\left(p_{1-2}>0,05\right)$. Через 3 доби в ГД-3 показник залишався істотно меншим, порівняно з ГД-1 та ГД-2 (від-

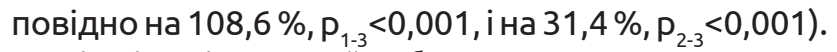
На відміну від першої доби максимальне значення 
Огляди літератури, оригінальні дослідження, погляд на проблему, ювілеї

Таблиця 2. Швидкість клубочкової фільтрації (мкл·хв를 з розрахунку на 100 г маси тварини в динаміці у групах дослідження, Me (LQ;UQ) - медіана (нижній і верхній квартилі)

\begin{tabular}{|c|c|c|c|c|}
\hline \multirow{2}{*}{ Групи дослідження } & \multirow{2}{*}{ Контроль } & \multicolumn{3}{|c|}{ Термін дослідження } \\
\hline & & 1 доба & 3 доба & 7 доба \\
\hline ГД-1 & \multirow{3}{*}{$\begin{array}{c}441,0 \\
(427,4 ; 457,4) \\
(n=8)\end{array}$} & $\begin{array}{c}159,5^{* * *} \\
(153,7 ; 168,9)(n=8)\end{array}$ & $\begin{array}{c}232,0^{* * *} \\
(216,4 ; 257,4)(n=8)\end{array}$ & $\begin{array}{c}240,7^{\star \star *} \\
(200,7 ; 266,3)(n=8)\end{array}$ \\
\hline гд-2 & & $\begin{array}{c}178,3^{* * *} \\
(160,3 ; 194,3)(n=8)\end{array}$ & $\begin{array}{c}146,1^{* * *} \\
(127,4 ; 170,8)(n=8)\end{array}$ & $\begin{array}{c}149,1^{* * *} \\
(132,3 ; 162,0)(n=8)\end{array}$ \\
\hline ГД- 3 & & $\begin{array}{c}126,4^{* * *} \\
(121,2 ; 136,7)(n=8)\end{array}$ & $\begin{array}{c}1111,2^{* * *} \\
(102,2 ; 118,2)(n=8)\end{array}$ & $\begin{array}{c}80,5^{* * *} \\
(71,9 ; 89,4)(n=8)\end{array}$ \\
\hline \multicolumn{2}{|l|}{$P_{1-2}$} & $>0,05$ & $<0,001$ & $<0,001$ \\
\hline \multicolumn{2}{|l|}{$P_{1-3}$} & $<0,01$ & $<0,001$ & $<0,001$ \\
\hline \multicolumn{2}{|l|}{$P_{2-3}$} & $<0,001$ & $<0,01$ & $<0,001$ \\
\hline
\end{tabular}

було в ГД-1 та достовірно більшим, порівняно $з$ ГД-2 (відповідно на 58,8 \% р $1-3_{2}<0,001$ ).

Через 7 діб показник залишався найнижчим в ГД-3, порівняно з ГД-1 та ГД-2 (відповідно на $199,0 \%, \mathrm{p}_{1-3}<0,001$, і 85,2 \%, $\left.\mathrm{p}_{2-3}<0,001\right)$. На відміну від ГД-3, в ГД-1 та ГД-2 показник до сьомої доби зріс та у тварин з реперфузійним синдромом був більшим на 61,4 \% ( $\left.p_{1-2}<0,001\right)$.

Аналізуючи динаміку швидкості клубочкової фільтрації у дослідних групах встановлено (рис. 2), що у ГД-1 показник через 1 добу досягав мінімальної величини, через 3 доби зростав і був на 45,5 \% більшим, ніж у попередній термін спостереження $(p<0,001)$. Через 7 діб показник повторно незначно зріс на $3,8 \%$ ( $>>0,05)$.

В ГД-2 показник знижувався поступово, проте вже з третьої доби досягав мінімальної величини (на 22,0 \% був меншим, ніж у попередній термін спостереження, $p<0,05)$ і незначно зріс через 7 діб, фактично залишаючись на попередньому рівні. В ГД-3 швидкість клубочкової фільтрації на 1, 3 та 7 доби була значно нижчою від контролю, при цьому мінімальне значення зафіксовано через 7 діб (на 38,1\%, p<0,05).

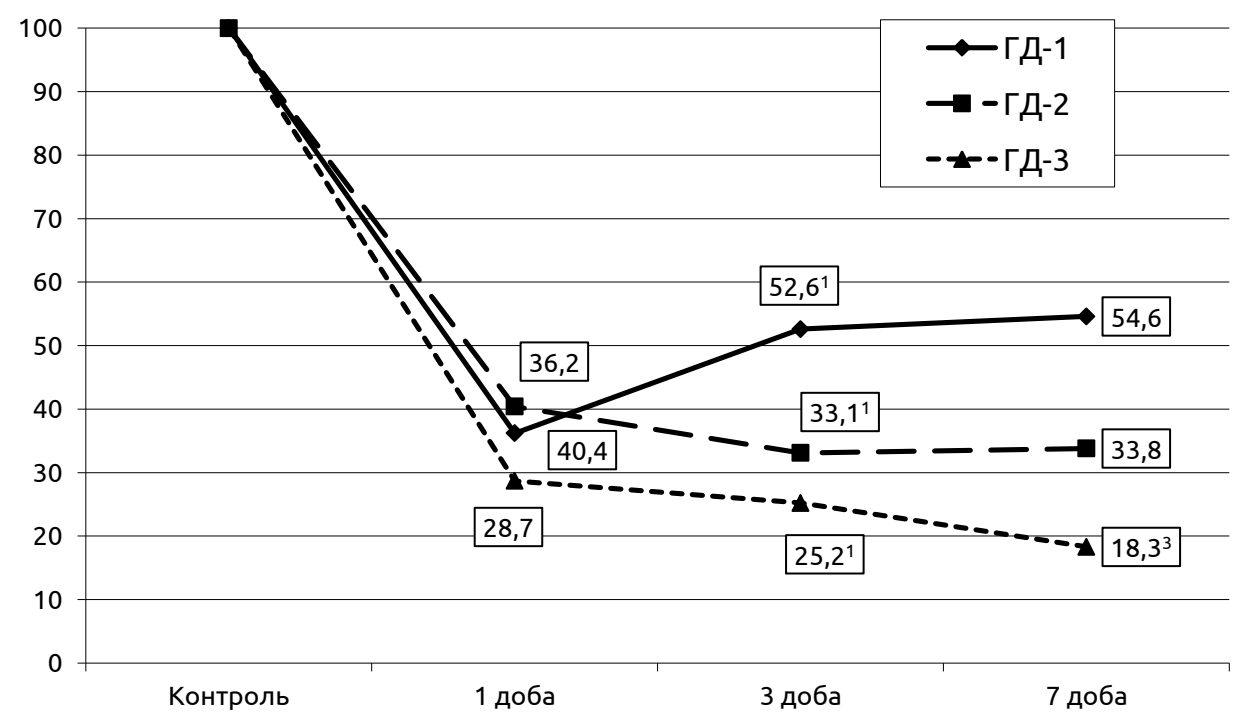

Рис. 2. Динаміка швидкості клубочкової фільтрації (у відсотках стосовно контрольної групи) в групах дослідження.

Аналізуючи вищевказане можна зробити висновок, що швидкість клубочкової фільтрації знижувалась у всіх групах піддослідних тварин. Наростання показника протягом часу спостереження визначено в ГД-1, хоча навіть після 7 доби він залишався вдвоє меншим за контрольні показники. В ГД-2 показник досягав мінімальних значень через 3 доби та залишався на цьому рівні до кінця спостереження, що відповідає класичній картині патофізіологічних змін у моделі поєднаної травми. Найвираженішими зміни були у тварин з поєднаною травмою та ішемічно-реперфузійним синдромом. Значне зниження показника спостерігали в усіх контрольних точках спостереження. 
Огляди літератури, оригінальні дослідження, погляд на проблему, ювілеї

Отримані в нашому дослідженні результати підтверджують дані інших авторів, які показали, що в патогенезі розвитку дисфункції нирок основну роль відіграє олігурія та зниження швидкості клубочкової фільтрації [6-10]. Однак у нашому дослідженні ми вперше показали, що ішемічно-реперфузійний синдром кінцівок значно посилює розлади функції нирок при закритій травмі органів черевної порожнини. Очевидно, що ішемія потенціює розвиток системної відповіді організму на запалення внаслідок викиду в системний кровотік цитокінів, порушення мікроциркуляції, гіпоксії та посилення процесу ліпопероксидації. Враховуючи значну чутливість тканини нирок до ендотоксинів та гіпоксії, зрозуміло, що ці чинники є основними у патогенезі розвитку ниркової дисфункції.

Висновки. 1. Ішемічно-реперфузійний синдром негативно впливає на динаміку діурезу в моделі поєднаної травми органів черевної порожнини на фоні масивної кровотечі. Визначено, що через 7 діб після травматичного періоду показник був достовірно меншим на 70,5 \% ( $p<0,001)$, порівняно із даними контрольної групи.

2. У всіх дослідних групах у ранньому післятравматичному періоді істотно знижується швидкість клубочкової фільтрації. Її величина в ГД-1 досягає мінімального рівня через одну добу з поступовим зростанням до сьомої доби спостереження. В ГД-2 та ГД-3 швидкість клубочкової фільтрації знижувалась до сьомої доби спостереження. Більш вираженими зміни були в ГД-3.

Перспективи подальших досліджень. У перспективі передбачається розробити патогенетично обґрунтовані засоби корекції системних змін, що виникають під впливом реперфузії кінцівки.

\section{ЛІТЕРАТУРА}

1. Center for Disease Control Prevention (2017). Estimated number of extremities visited to ed and cost of injury reports. Available online at: https://wisqars.cdc.gov:8443/ cost.

2. Tourniquet use for civilian extremity trauma / K. Inaba, S. Siboni, S. Resnick [et al.] // J. Trauma Acute Care Surg. 2015. - No. 79. - P. 232-237.

3. Malek Maryam. Renal ischemia/reperfusion injury; from pathophysiology to treatment / Maryam Malek, Mehdi Nematbakhsh // J. Renal Inj. Prev.-2015. - Vol. 4 (2). -P. 20-27.

4. Unilateral renal ischemia-reperfusion as a robust model for acute to chronic kidney injury in mice / Nathalie Le Clef, Anja Verhulst, Patrick C. [et al.] // PLoS One-2016. Vol. 11 (3). - P. 7.

5. Promotion of cell proliferation by clusterin in the renal tissue repair phase after ischemia-reperfusion injury / C. Y. Nguan, Q. Guan, M. E. Gleave, C. Du // Am. J. Physiol. Renal Physiol. - 2014. - Vol. 306. - P. 724-733.

6. Oxburgh L. Ischemia-reperfusion injury of the mouse

\section{REFERENCES}

1. (2017). Center for Disease Control Prevention. Estimated number of extremities visited to ed and cost of injury reports. Retrieved from: https://wisqars.cdc. gov:8443/cost.

2. Inaba, K., Siboni, S., Resnick, S., Zhu, J., Wong, M. D. Haltmeier, T., et al. (2015). Tourniquet use for civilian extremity trauma. J. Trauma Acute Care Surg., 79, 232-237.

3. Maryam Malek \& Mehdi Nematbakhsh (2015). Renal ischemia/reperfusion injury; from pathophysiology to treatment. J. Renal Inj. Prev., 4 (2), 20-27.

4. Nathalie Le Clef, Anja Verhulst, Patrick C. D'Haese, Benjamin, A. (2016). Vervaet (2016). Unilateral renal ischemia-reperfusion as a robust model for acute to chronic kidney injury in mice. PLoS One, 11 (3), 7.

kidney / L. Oxburgh, M. P. de Caestecker // Methods Mol. Biol. - 2012. - Vol. 886. - P. 363-379.

7. Post-traumatic acute kidney injury: a cross-sectional study of trauma patients / Lai Wei-Hung, Rau Cheng-Shyuan, Wu Shao-Chun [et al.] // Scand. J. Trauma Resusc. Emerg. Med. - 2016. - Vol. 24. - 136 p.

8. Бойчук Т. М. Патофізіологія гепаторенального синдрому при гемічній гіпоксії / Т. М. Бойчук, Ю. Є. Роговий, Г. Б. Попович. - Чернівці : Медичний університет, 2012. -192 c.

9. Мерлєв Д. І. Динаміка функціонального стану нирок в умовах скелетної, черепно-мозкової та поєднаної травм у період ранніх проявів травматичної хвороби / Д.І. Мерлєв, А.А. Гудима//Вісник науковихдосліджень.2014. - № 2 - С. 90-93.

10. Пішак В. П. Характеристика функціонального стану нирок у гострому періоді експериментальної політравми / В. П. Пішак, А. О. Коган // Бук. мед. вісник. 2009. - Т. 13, № 1. - С. 88-92.

5. Nguan, C.Y., Guan, Q., Gleave, M.E., \& Du, C. (2014). Promotion of cell proliferation by clusterin in the renal tissue repair phase after ischemia-reperfusion injury. Am. J. Physiol. Renal Physiol., 306, 724-733.

6. Oxburgh, L., \& de Caestecker, M.P. (2012). Ischemiareperfusion injury of the mouse kidney. Methods Mol. Biol., 886, 363-379.

7. Wei-Hung Lai, Cheng-Shyuan Rau, Shao-Chun Wu, Yi-Chun Chen, Pao-Jen Kuo, Shiun-Yuan Hsu, Ching-Hua Hsieh, Hsiao-Yun Hsieh (2016). Post-traumatic acute kidney injury: a cross-sectional study of trauma patients. Scand. J. Trauma Resusc. Emerg. Med., 24, 136.

8. Boichuk, T.M., Rohovyi, Yu.Ye., \& Popovych, H.B. (2012). Patofiziolohiia hepatorenalnoho syndromu pry 
Огляди літератури, оригінальні дослідження, погляд на проблему, ювілеї

khimichnii hipoksii [Pathophysiology of hepatorenal syndrome when chemical hypoxia]. Chernivtsi: Medychnyi universytet [in Ukrainian].

9. Merliev, D.I., \& Hudyma, A.A. (2014). Dynamika funktsionalnoho stanu nyrok v umovakh skeletnoi, cherepno-mozkovoi ta poiednanoi travm u period rannikh proiaviv travmatychnoi khvoroby [Dynamics of the functional status of the kidneys in conditions of skeletal, craniocerebral and combined traumas during the period of early manifes- tations of traumatic illness]. Visnyk naukovykh doslidzhen - Journal of Scientific Researches, 2, 90-93 [in Ukrainian].

10. Pishak, V.P. \& Kohan, A.O. (2009). Kharakterystyka funktsionalnoho stanu nyrok u hostromu periodi eksperymentalnoi politravmy [Characteristics of the functional state of the kidneys in the acute period of the experimental polytrauma]. Buk. med. visnyk - Bukovyna Medical Journal, 13 (1), 88-92 [in Ukrainian].

СОСТОЯНИЕ СУТОЧНОГО ДИУРЕЗА

\section{ПОЧЕК В УСЛОВИЯХ ИШЕМИЧЕСКИ-РЕПЕРФУЗИОННОГО СИНДРОМА КОНЕЧНОСТЕЙ, ТРАВМЫ ОРГАНОВ БРЮШНОЙ ПОЛОСТИ, ОСЛОЖНЕННОЙ ГИПОВОЛЕМИЧЕСКИМ ШОКОМ, И ИХ СОЧЕТАНИЯ В РАННИЙ ПЕРИОД ТРАВМАТИЧЕСКОЙ БОЛЕЗНИ}

๑Г. Ю. Цымбалюк

Гвуз «Тернопольский государственный медицинский университет имени И. Я. Горбачевского МЗ Украины»

РЕЗЮМЕ. Цель работы - изучить влияние ишемически-реперфузионного синдрома на функциональное состояние почек в раннем послетравматическом периоде.

Материал и методы. В эксперименте использовали 80 половозрелых белых крыс-самцов линии Wistar массой 190-220 г, которые находились на стандартном рационе вивария.

Всех животных поделили на группы: контрольную и 3 исследовательских (по 8 животных в каждой группе). у животных первой опытной группы под тиопенталнатриевым наркозом (40 мг·к $\left.\Gamma^{-1}\right)$ проксимально на нижние лапки накладывали кровоостанавливающий жгут сроком на 120 мин. Во второй исследовательской группе была смоделирована сочетанная травма органов брюшной полости путем нанесения двух дозированных ударов в область брюшной полости; гиповолемический шок моделировался путем кровопускания от 20 до 22 \% объема циркулирующей крови из бедренных сосудов. В третьей опытной группе моделировали сочетанную травму органов брюшной полости и реперфузии конечностей. Животных контрольной группы вводили только в наркоз.

Через 1, 3 и 7 суток у подопытных животных определяли функциональное состояние почек методом водной нагрузки. Оценивали величину диуреза и скорость клубочковой фильтрации.

Животных опытных групп выводили из эксперимента в условиях тиопентал-натриевого наркоза методом тотального кровопускания из сердца.

Результаты. В группе животных после наложения жгутов на нижние конечности после первых суток существенно снижается диурез и имеет минимальные значения, в дальнейшем показатель увеличивался, однако был меньше уровня контрольной группы даже через 7 суток (меньше на 33,6 \% ( $<<0,05)$ по сравнению с контролем). В группе животных с травмой органов брюшной полости и гиповолемическим шоком показатель достигал минимального уровня через 3 суток и фактически оставался на том же уровне до 7 суток. В группе животных, которым моделировали травму органов брюшной полости, кровотечение и наложения жгутов на задние конечности, наблюдалась тенденция к постоянному снижению показателя в течение всего времени наблюдения. Его минимальные значения зафиксировали через 7 суток (меньше на 33,6 \% ( $<<0,05)$ по сравнению с контролем). Скорость клубочковой фильтрации снижалась во всех группах подопытных животных. Нарастание показателя в течение времени наблюдения определено в группе животных с наложением жгутов, хотя даже после 7 суток он оставался вдвое меньше контрольных показателей. В группе животных с травмой органов брюшной полости и гиповолемическим шоком показатель достигал минимальных значений за 3 суток и оставался на этом уровне до конца наблюдения, что соответствует классической картине патофизиологических изменений в модели сочетанной травмы. Наиболее выраженными изменения были у животных, у которых сочетались политравма и ишемически-реперфузионный синдром. Значительное снижение показателя наблюдалось в течение всех точек наблюдения.

КЛючЕВЫЕ СЛОВА: диурез; почки; травма; реперфузионный синдром; эксперимент. 


\section{Огляди літератури, оригінальні дослідження, погляд на проблему, ювілеї}

\section{DAILY URINE RENAL STATE UNDER ISCHEMIC-REPERFUSION SYNDROME OF LIMBS, ABDOMINAL INJURY WITH HYPOVOLEMIC SHOCK AND THEIR COMBINATION IN THE EARLY PERIOD OF TRAUMATIC DISEASE}

\section{Horbachevsky Ternopil State Medical University}

@H. Y. Tsymbaliuk

SUMMARY. The aim of the work - to study the effect of ischemic-reperfusion syndrome on the functional state of the kidneys in the early post-traumatic period.

Material and Methods. In the experiment, there were 80 sexually mature white male Wistar rats, weighing 190$220 \mathrm{~g}$ on a standard vivarium diet.

All animals were divided into groups: control and 3 experimental ( 8 animals in each group). In animals of the first experimental group under the thiopental-sodium enzymes $\left(40 \mathrm{mg} \cdot \mathrm{kg}^{-1}\right)$ proximal to the left paws imposed a hemostatic tourniquet for 120 minutes. In the second experimental group, a combined injury to the abdominal cavity was simulated by applying two dose injections to the abdominal region; Hypovolemic shock was modeled by bloodletting from 20 to $22 \%$ of the volume of circulating blood from the femoral vessels. In the third experimental group, a combined injury to the abdominal cavity and reperfusion of the extremities was simulated. Animals of the control group were administered only in anesthesia.

After 1, 3 and 7 days in experimental animals, the functional status of the kidneys was determined by the method of water loading. Diuresis and velocity of glomerular filtration were evaluated.

Animals of experimental groups were extracted from the experiment under conditions of thiopental sodium anesthesia by the method of total blood-flow from the heart.

Results and Discussion. In the group of animals, after the overhangs on the lower extremities, after the first day, the diuresis significantly decreases and has minimal values; furthermore, the index increased but did not reach the control group even after 7 days $(33.6 \%$ less, $(p<0.05)$ in comparable to control). In the group of animals with trauma of the abdominal cavity and hypovolemic shock the index reached the minimum level in 3 days and actually remained at the same level by the seventh day. In the group of animals where the trauma of the abdominal cavity was combined, bleeding and overlapping of the harness on the lower extremities, there was a tendency towards constant decrease of the index throughout the observation time. Its minimum values were recorded after 7 days (less by $33.6 \%$ ( $p<0.05$ ) compared to control). The velocity of glomerular filtration decreased in all groups of experimental animals. The increase in the indicator during the observation time was determined in the group of animals with overlapping of harnesses, although even after 7 days it remained two times lower than control values. In the group of animals with trauma of the abdominal cavity and hypovolemic shock, the index reached the minimum values after 3 days and remained at this level until the end of the observation, which corresponds to the classic picture of pathophysiological changes in the model of combined trauma. The most pronounced changes were in animals with combined trauma and ischemic-reperfusion syndrome. Significant decrease of the index was observed during all control points of observation.

KEY WORDS: urine output; kidney; injury; reperfusion syndrome; experiment. 